\title{
Plagiarism and other scientific misconducts
}

\author{
K. Höffken · H. Gabbert
}

Received: 16 December 2008/ Accepted: 16 December 2008/Published online: 6 January 2009

(C) Springer-Verlag 2008

When we were young scientists we heard that: "games authors play" and learned that results of scientific work was published by the same authors in different order in different journals. However, the content of the publications differed only slightly from each other (e.g., by omitting one and adding another table or figure) and the conclusions were almost identical.

When we grew older, we encountered affairs of scientific misconduct ranging from copying text from other scientific papers up to faking results.

When we became editors of our journal, we hoped that we would be immune from such assaults. However, we had to learn that each of the above examples of plagiarism and of other scientific misconduct could happen to us. We met double publications, learned that authors sent manuscripts simultaneously to more than one journal or were informed that authors copied and pasted text (as can be seen from the example below).

\begin{tabular}{|c|c|}
\hline Original version & Plagiarized version \\
\hline $\begin{array}{l}\text { Recent technologic advances now } \\
\text { make it feasible to better tackle } \\
\text { the methodological challenges } \\
\text { of detecting EBV in breast } \\
\text { cancers. Consequently, a } \\
\text { critical next step in } \\
\text { understanding this relationship } \\
\text { is to apply detection strategies } \\
\text { that are sensitive and specific } \\
\text { for EBV and able to localize } \\
\text { the EBV to particular benign or } \\
\text { malignant cells within the } \\
\text { tissue. A recent National } \\
\text { Cancer Institute } \\
\text { recommendation specifies an } \\
\text { approach combining real-time } \\
\text { quantitative PCR, which allows } \\
\text { measurement of the amount of } \\
\text { viral DNA in archival tissue } \\
\text { samples, with laser capture } \\
\text { microdissection to improve } \\
\text { localization of viral DNA to } \\
\text { benign or malignant } \\
\text { components of a tissue sample } \\
\text { (90). }\end{array}$ & $\begin{array}{l}\text { Recent technological advances } \\
\text { now make it feasible to better } \\
\text { tackle the methodological } \\
\text { challenges of detecting virus in } \\
\text { breast cancers. A critical next } \\
\text { step in understanding this } \\
\text { relationship is to apply } \\
\text { detection strategies that are } \\
\text { sensitive and specific for virus } \\
\text { and able to localize this agent } \\
\text { to particular malignant cells } \\
\text { within the tissue. A recent } \\
\text { National Cancer Institute } \\
\text { recommendation specifies an } \\
\text { approach combining real-time } \\
\text { quantitative PCR, which allows } \\
\text { measurement of the amount of } \\
\text { viral load in archival tissue } \\
\text { samples, with laser capture } \\
\text { microdissection to improve } \\
\text { localization of viral nucleic } \\
\text { acid to benign or malignant } \\
\text { components of a tissue sample. }\end{array}$ \\
\hline
\end{tabular}

What did we learn from these facts?

1. Science is not immune from fraud, misconduct nor void of bad scientists. Fortunately, these are exemptions!

2. Journals are not protected against these assaults and

3. Even the best prevention system did not exclude that it happened to us and that it will happen again.

What can we do to improve our prevention mechanisms?

1. We count on the readiness and awareness of our readers. 
2. We will relentlessly denounce the criminal methods and their originators.

3. We will put the persons on a black list and urge other journals to deny them the right for publication.
Please support us with our efforts. Do not hesitate to inform us about any irregularity, violation or infringement. 